University for Business and Technology in Kosovo

UBT Knowledge Center

UBT International Conference

2013 UBT International Conference

Nov 1st, 2:40 PM - 2:50 PM

\title{
Public management, public administration, public policies and antidiscrimination measures in Kosovo
}

Shkendije (Demalijaj) Ukaj

Tax Administration of Kosovo, sh_demalijaj@yahoo.com

Follow this and additional works at: https://knowledgecenter.ubt-uni.net/conference

Part of the Business Commons

\section{Recommended Citation}

Ukaj, Shkendije (Demalijaj), "Public management, public administration, public policies and antidiscrimination measures in Kosovo" (2013). UBT International Conference. 29.

https://knowledgecenter.ubt-uni.net/conference/2013/all-events/29

This Event is brought to you for free and open access by the Publication and Journals at UBT Knowledge Center. It has been accepted for inclusion in UBT International Conference by an authorized administrator of UBT Knowledge Center. For more information, please contact knowledge.center@ubt-uni.net. 


\title{
Public management, public administration, public policies and antidiscrimination measures in Kosovo
}

\author{
Shkendije (Demalijaj) Ukaj \\ Tax inspector, Tax Administration of Kosovo, Peja Region \\ sh_demalijaj@yahoo.com
}

\begin{abstract}
One of the main motivations for the implementation of public administration reform in the countries of Central and Eastern Europe is the entry into the European Union, such a thing is true for the Republic of Kosovo. Public administration of any state that will approach the European Union should reach the level of confidence in the implementation of the acquis communautaire and the quality level of the administration which exists within the European Administrative space. Public administration refers to the work that perform governmental institutions and includes the development and implementation of public policies. Political parties adopt inclusive models of policy development for a number of different reasons. Some parties mention values or ideological basis reason for the involvement of citizens in policy-making. Others are practical, emphasizing the fact that consultation often brings stronger policy opportunities, and most important. For example, policies for the development of the central and local budgets that include views of economic experts together with users of public goods, are more likely to be realistic, meaningful and applicable. Public consultation on public policy making is becoming a universal standard in European governance. Under ECrules, using public consultation to develop policies and legislation ensure that policy proposals are technically possible and practically feasible. In other words, such consultation dual purpose shall be applied in Kosovo by assisting in the improvement of the quality of the policy outcome as a condition for European integration. Economic and social development of any country can not be understood without a treatment and concrete achievements in the development and implementation of antidiscrimination policies by central and local government institutions.
\end{abstract}

Keywords: Public Management, Public Administration, Public Services, Public sector, Governance.

\section{Introduction}

This paper focuses on public administration and public policy and to the public administrator or citizen that seeks to influence public policy through government agencies or non-profit. For this reason we have reviewed the details of the institutions, processes and techniques of working in the public sector. What is more important is the perception of the real world of public service, from the perspective of the citizen. "The administration's public policy". However, management must lies outside the sphere of politics. Adminis trative is sues are not political is sue nonetheless establishes policies for managing tasks, the latter must not suffer from political manipulation. In other words, while policies are discussed and decided by the politicians they should be implemented by a politically neutral body bureaucrats professionals. In this way, the daily operations of government will isolate the potential impact of political corruption character. This field therefore requires the development of certain skills to operate effectively and responsibility. This includes, inter alia, terms of governance institutions and processes ; magnifying underlying values of public service; technical skills in areas such as developing programs , budgeting and human resources; interpersonal and communication skills, leadership and decision making as and the capacity to unite and integrate all this knowledge and values. The structure ofpublic organizations should be influenced by democratic values, most specifically from anxiety to act in the public interest whether perform their activity in the central or local level. A statutory manager will definitely be related to the legislature. Most importantly is that the legislature will decide which tasks 
will fulfill the relevant agency, human and financial resources that will be available yen and will supervise the activities of the executive. Also the involvement of the courts is inevitable in the work of administration. Public administration reform in Kosovo unless definitely things that need to happen in that regard that the government should be accountable not only for its activities but should be evaluated its capacity to achieve substantial public purposes, in an effort to improve the quality and productivity them. Progress of information technology plays an integral role in the transformation, public organizations worldwide. Also to be taken into account in public policy reforms (mainly tax) pertaining to public expenditure and their role in the economic welfare of society. And while examine various aspects of the reforms should address the questions : Are improve services to the public in terms of increasing their welfare? And a work that is carried out in accordance with a system of democratic governance? Also notable is concern about discrimination in the performance evaluation process at work and the process of hiring and treatment of employees in public agencies .

\section{Aspects of public management}

A healthy system of public management requires taking into consideration the values and demands of society. Accountability, transparency, predictability and participation are important tools for a healthy public management, but they also have a value of their internal and considered four main pillars ofgood governance. Good governance refers first and foremost within the frameworks which establish and execute public policies. Effective public governance should provide coherence between different policy objectives and an environment in which people are treated with fairness and equalit. In modern society, citizens expect honesty from the people in charge of carrying out activities in the public sector. As regards norms and processes, they are important for the implementation of the rights of citizens and public services for the development of customer -oriented. That corruption is misuse of authority by public officials and private for personal gain, directly or indirectly, causes moral and legal problems and is the main source of inefficiencies in public management. Of course, a road that leads to strengthening public management is to reduce the level of corruption and the punishment of those involved in corruption. Corruption in government is frequently associated with major procurement transactions and major public works projects.

Often in countries in transition, inspectorates traditional focus on small irregular, while serious cases of corruption remain unaddressed and unpunished, a phenomenon that is happening in Kosovo. Such cases are often the hidden part of the annual budget, as are secondary obligations, costs outside the budget and expenditure commitments us long but not limited to the systems weak tax administration, debt management, customs administration, are being privatisation equally resource -corruption and fraud. Fiscal transparency and accountability and audit systems in place are essential to combat corruption in these areas. As noted above public service management is a specific culture of the country and its administration. For modernization of public management in countries in transition, it is important to understand the cultural heritage of society commanded by which they flow. Command societies, the main functions of government were planning general organization and production of goods and services. In most of these countries, the most important document was the plan. Although many functions were to be performed by the state budget resources that flowed directly on this plan, the role of the state budget was less important than in market economies. There is very clear on what do deal basis for resource allocation decisions inline various categories are as production, investment, social payments and defense. It seems that such decisions are taken as a result of the power of the party leadership. Resource distribution system was not supported neither to vote nor in competition between firms decentralized state. In their place, he usually included political leaders inline negotiations for determining the state budget, which will protect the interests of the state and political negotiating position.

Thus, large-scale real objectives of the state budget to ensure es sential for the survival of the political leadership, to provide political information and give the impression that the national ideology is on the right path. 


\subsection{New Public Management}

New Public Management is a concept born in seventy (70) years in the neoliberal premises, which aims to modernize the management of public administration. It is based on the division of roles between the political power takes strategic decisions and operational administration to take decisions. The basic postulate of the new public management is that in terms of new development, classical forms of organization of state must fundamentally revised. A centralized welfare state would not be efficient enough complexity facing the world. Administrative services responsible for operational implementation of policies need to possess sufficient freedom in allocating resources at their disposal and techniques needed for this budget affordable therefore requires the application of public sector management methods that come from the private sector so to enter the market principles that are considered more efficient than planned. Implementation of the new public management in the world articulated around the following organizational reforms necessary for the implementation in Kosovo:

- Creating market for sectors that were once considered public property .

- Separation of powers between the one who decides and executes him that .

- Decentralization of the state, the creation of public agencies contract with the state .

- Replacement of hierarchical procedures with contractual procedures .

- Public agencies to put in competition among themselves or with private agencies to award public service central government .

- Agencies responsible for the management of state and therefore their citizens, they continually evaluated through management indicators .

- Employee of the agency are no official status, they evaluated and paid according to merit rather than seniority .

- Ways of inspired human resources management from the private sector.

- Users of public services to become customer service pay .

The new public management is largely inspired by state reforms carried out in the United Kingdom, New Zealand and Sweden. However there are some fundamental differences between public sector and private defiance: Missions of civil servants are defined in political terms and not contractual, the public services of general interest seen despite specific interests, the responsibility of public servants to the government and citizens is different from utility executives you expect profits but not fastened missions; public services do not choose their clientele. Besides this organization Structure countries have very outdated that are historically associated with specific tasks carried out for many years it was difficult to re-run, there are places where unions are strong public functions, there is also strong resistance to change in administration related with their bureaucratic bodies and their protection from the market. Implementation of the new public management has also brought its negative effects to unforeseen: public governments have lost the capacity for coordination and planning of public action; agencies become increasingly autonomous and tend to withdraw from public power Directives; agencies since the specialized are unable to cope with new problems, they neglect the needs of society in favor of their internal efficiency. According to some analysts the implementation of new public management and administration has reduced performance and in some cases it is accompanied by degradation of its services rendered. Analysts point out that these failures appear to be associated with the idea that the market mechanism always bring optimal choice but it is not always efficient solution. Agencies often focus on the production of statistical data without actually assessed the results of a specific action. Despite this new public management, the European Union has created a space -based administrative culture results although it appears different culture inside each Member State. Improving public expenditure management in transition countries including Kosovo. Transition countries recognize the importance of efficiency in the management of government spending and are undertaking a series of reforms in this area. However, while many obstacles encountered in mass different from one country to another depending on the Inheritance of the previous regime. In countries in transition, the tendency for decisions imposed from above, without proper consultations and coordination still bring inefficiency in policy development and implementation. The distribution of responsibilities is often not clearly defined between the finance ministry and line ministries. Developing systems for procurement law and is not regular. Achieving the standards set by the EU Member States in the man agement of public expenditure is one of the most important challenges for the region, including Kosovo, which claim to join the EU . 
Distribution and efficient use of EU funds that require the undertaking of a series of reforms to public expenditure management that have as main purpose the implementation of key elements of best practice in drafting the budget systems and fulfillment of specific criteria to EU for the member states.These criteria are: Institutional framework, clearly defined principles should be included in the country's constitution, the organic budget law and other laws associated with it. The regulatory framework should ensure a balance between the legislative and executive powers . Parliament should examine and discuss how to budget and fiscal policies . For maximum efficiency and better macroeconomic management in the allocation of resources, the budget should include all revenues and expenses, as sources of EU funding should be included in the national budget. Medium-term fiscal framework next - Members of the EU should be able to provide information on the context of the budget in the medium term, mediumterm fiscal objectives and provide for review of the stability and convergence programs. The process of drafting the budget, should be clear and understandable in all its stages . Budgeting procedures and operating costs should be integrated investment. It should specify the objectives of the government on fiscal policy, macroeconomic framework, budgetary policies and major fiscal risks. Budget information must be provided to the public in a clear and easy to consult. Implementation and monitoring of the budget, line ministries should implement the spending limits set by parliament and to submit regular reports to the Ministry of Finance which shall monitor and controlled the flow of expenditure during the year through a unified system of financial accounts. Parliament and the council of ministers should hold responsibility for reviewing periodic reports on financial performance and policy review as a result of changes in economic and political circumstances. Cash management should be under the control of the Ministry of Finance through the Unified Treasury Account. Budget and accounting should have the same classification system to make it easier for policy analysis and increase accountability. Fiscal reports should be made in time and be inclusive and to identify deviations from the budget. Should establish procedures for assessing the efficiency and effectiveness of programs and policies to expenditures including those funded by the EU. Audit - an internal audit mechanism should be efficient, then you meet the following criteria: be independent, to have a full audit mandates and to use the internationally recognized standards of auditing to prevent irregularities and coverage amounts lost as a result of irregularities and negligence. Procurement systems - one of the goals is essential for good governance functioning market economy as the order of priority of the EU. A healthy political reduce the cost of procurement of public spending, give results in shorter time, foster private sector development, reduces delays, corruption and inefficiency governance. Measures for the improvement of procurement include: a comprehensive public procurement, the establishment of a central body with responsibility for the design and implementation of public procurement policy and national training programs, establish effective control and review complaints regarding procedures.

Budget management of EU funds, the European Commission considers that the candidate countries for membership in the EU should be prepared to manage the funds before memberships, so that when they join the EU have the required budget and instruments.

\subsection{Management reform process}

The reform will succeed only if there will be support or supporters in government. Financial reforms require leadership commitment to leading the finance ministry. It is crucial to reach a consensus between the various participants in the reform, the finance ministry should cooperate closely with line minis tries, other leaders who depend on government institutions and other important participants. Advising the legislation is very important. Dissemination of information regarding the proposed reform to members of parliament and the public is very important for ensuring the constancy of the reform that requires a period of 5-10 years. Therefore, in terms of requirements arising from the process of European integration, the EU has set a number of requirements to be met Kosovo related to the acquis especially regarding issues such as: The effective functioning of Parliament by strengthening its capacity to monitor effectively implementing and evaluating the implementation of the legislation, by improving administrative structures, legaland advis ory ${ }^{1}$. Ensure respect for the separation of powers, particularly the exercise of the executive supervision activity increased, while at the same time ensuring transparency of Parliament through cooperation with civil society, as you claim is repeated in the Progress Reports ${ }^{2}$. In detail, these requests related to placing and effective implementation mechanis ms for supervision of the work of the Government, eg screening through the implementation of the 
framework strategy reports, annual government reports, annual reports on budget implementation legislation, through parliamentary questions, interpellations etc ${ }^{3}$., Improve the compatibility control legislation with the acquis which includes adequate mechanisms to evaluate proposed legislation in the later stages of effective supervision of this process of harmonization of legis lation with the acquis ${ }^{4}$. Although recent efforts seemto have been developed to increase the level of supervision activity of the Parliament over the executive nonetheless remains dominated Assembly Government ${ }^{5}$. Government officials do not attend on a regular sessions of the Assembly, and not responded adequately to parliamentary questions and reporting requirements ${ }^{6}$. A considerable part of the recommendations and decisions of the Assembly shall not be taken into account, which greatly limits the exercise of supervisory functions over the executive ${ }^{7}$. The Assembly also remains to be further strengthened its capacity to supervise the executive, even as far as the monitoring and implementation of legislation in general, but also in terms of budget expenditures ${ }^{8}$. Parliament is facing a number of challenges in the exercise of supervisory function as its limited sensitivity of assembly members the importance of supervisory function; resistance executive for cooperation and the provision of information in line with the legislation in force, the number not sufficient guidance staff; no allocation for external expertise and research capacity to remain low ${ }^{9}$. Although progress has been made regarding their supervision activity fulfilling that function approximation and harmonization with the acquis nevertheless remain a number of challenges to be overcome, as a result of insufficient expertise as well as the other institutions of the country, and the number of insufficient relevant staff. Then deficient communication between

the political and administrative level. Political interference in the recruitment and promotion of staff ${ }^{10}$ remain worris ome. Yet there is no special training strategy for the as sembly staff and budget allocated for this remains unspent ${ }^{11}$. While it is being finalized harmonization of regulations for the organization and responsibilities of the Administrative Assembly with legislation on civil servants', which would provide a legal basis for recruitment and promotion based on merit. In 2011, Kosovo has started to prepare the State Partnership Strategy ( SPSH ) which is the first since Kosovo declared independence in February 2008 and became a member of the International Monetary Fund ( IMF ) and World Bank Group ( WBG ) in mid 2009 . This crap spsh order to ensure harmonization of national development priorities of the Government in the context of the country's as pirations for EU integration. The strategy will be financed mainly by a division of funds from IDA As Kosovo is a state only in IDA. Allamounts will depend heavily on the performance of his country. IDA is expected to spsh will give funds ofabout U.S. \$ 76 million completed the \$ 66 million grant from IDA donors through the International Finance Corporation ( IFC) is expected to directly finance private sector about \$ 40-50 million and funds additional advisory services, and will mobilize additional funds from other financial institutions and will provide its own financing in the energy sector. Agency Multilateral Investment Guarantee ( AMIG ) will also consider issuing a guarantee against political risk in this sector. The politicization of public administration and reforms in the administration remain serious obstacles to the transformation of public administration competent administration, based on the value and merit, in a sustainable and efficient administration that serves the needs of citizens. The fight against corruption is the government's negative campaign is more than the fight against this phenomenon. Ethics is also a very important part of the work of a public administrator. The implementation of ethical is sues is up to public administrators responsible, conscious and who faithfully preserve not only the institutional integrity of their agency but use it to fulfill its mission.Therefore the socio political and economic changes in Kosovo is a need to reform the adminis tration in order to increase the quality of services for citizens and businesses, and includes completion of legal infrastructure, administrative capacity building and technological advancement functioning administration that in some institutions have already started to apply EGovernance. The reform process is aimed at creating a modern administration, functional, professional , politically neutral, transparent, efficient and accountable to the needs of citizens, with a horizontal and vertical effective organization of public administration institutions in accordance with their responsibilities, where effective communication and mutual with citizens in policy development and service delivery is considered crucial to the performance of a modern public administration in compliance with European and international standards.

\section{Public Administration and the rule of law}


Kosovo ranks rather weak in many dimensions of governance. The latest progress report of the European Council (EC) more widespread corruption and weakness in the rule of law inhibit private investment and in turn, create jobs. Other sources also reinforce these findings. World Governance Indicators for 2010 placed Kosovo under the average for Europe and Central Asia Government effectiveness and control of corruption. The Global Integrity Index assesses Kosovo as too weak on accountability of government, administration and civil service. Poor administration directly manifested in weak service delivery ranging from social services to the police and courts. The government has initiated many reforms and has adopted some laws, but implementation is slower. Public policies in the field of rule of law in Kosovo represent one of the main challenges for Kosovo. Given the fact that Kosovo is in the process of building democratic institutions, problems in the field of rule of law are not small. Kosovo Police particular component of the judiciary and prosecution that are responsible for the rule of law are weak showing so far in the sustainable functioning of the rule of law.

\subsection{Training staff}

Rationalizing organizational structures, modernization of procedures, processes and implementation of a computer-generated program can be easily reversed without a stay operational staffdo not understand and supports the changes. This requires taking action in order to give support to change and change communications to and through the middle management level, in order to achieve the cooperation and approval of civil service managers and operational staff. Such actions include seminars and distribution of the documents to reform. Training programs for each of the components of the reform were important for the successful implementation of the reform, which should cover several areas such as training of accountants to use new accounting procedures, training of high level, specialized training in areas such as training of information technology specialists, training specialists and macroeconomics as general teaching of foreign languages, computer programs, etc.

\subsection{Gender Inequality}

Gender inequality is present in the world, but even more in Kosovo, which suffers from the heritage of patriarchal society and the difficult economic restrictions. Gender stereotypes continue to be strong even in the labor market. The majority of employed women continue to work in occupations which have been traditionally concentrated on how to : education, health, etc. . While traditionally men continue to hold leadership positions and in all decision making bodies that regulate the labor market. Also businesses are mainly in the hands of men. This lower activity participation for women among the lowest in the Western Balkans, is partly associated with a disproportionate share of household responsibilities, lack of opportunities for child care and an inadequate access to flexible working arrangements. The unemployment rate is significantly higher for women ( $56 \%$ ) than for men ( $41 \%$ ) and is higher for both sexes in the region. In the end, even though Kosovo has con siderable progress in raising voice of women in political decision-making, participation of women in government leadership positions remains low .

\section{Recommendations}

Respect for the separation of powers and Surveillance effective harmonization process with the EU legislation in order to meet the objectives for the European integration of Kosovo. Improving the management of public finances and strengthen public investment management, consolidated procurement,and transparency in payroll management.. Continuous commitment Interagency coordination with governmental and local stakeholders for reform of international public administration in general, to overcome every challenge in terms of professionalism and further modernization of public administration .Further de-politicization during recruitment and promotion in the public service . Capacity building of officials in all areas through training and evaluation of the performance to be made based on merit to build institutions with high performance and integrity, and not entirely in partisan basis. Increase human capacity of the rule of law institutions and cooperation between these ins titutions to take action against corruption, the punishment of those who are involved in the confiscation of wealth and acquired illegally. Full implementation of control and accountability and transparency measures 
against officials all fields and at all levels of government, and it will contribute to increasing the social and economic welfare of the country.

\section{References}

1. Geuras,D. and Garofalo,C. (2010), "Etika Praktike ne Administraten Publike", Tirane, U.F.O.Pres, Bot. II, fq.28-30.

2. Hutsebaut, M.(2013), "Politikat Tatimore sipas kendveshtrimit Europian"fq.3.

3. http://www.bspk.org/PDF/4_4_13pdf

4. IPOL: (2011), Instituti Ballkanik I Politikave, " Politikat Publike ne fushen e sundimit te ligjit ne Kosove", Prishtine,fq.1-2.

5. http://policyinstitute.eu/alb/publications/public policy in the field of rule of law/

6. Instituti Kombetar demokratik(NDI): (2011), " Partite politike, politikat publike dhe demokracia pjesemarrese", Tirane, fq.8.

7. http://www.ndialbania.org/.../partite\%20politike

8. OECD:(2004), Menaxhimi I shpenzimeve publike/Nje liber reference per vendet ne tranzicion, Edituar nga: Richard Allen dhe Daniell Tommasi, ILAR, Tirane, fq.21-35.

9. Pajaziti,A. (2005),"Etika Publike, Logos-A, Shkup.

10. Republika e Shqiperise: Ministria e Punes dhe Qeshtjeve Sociale; Komiteti Per Barazi Ginore dhe UNDP ( Albania),"Perkatesia Giinore dhe punesimi ne Shqiperi, Tirane, Korrik 2005, fq.38-39.

11. USAID: (2010), "Plani Strategjik i Kosoves 2010-2014", Prishtine, fq.6.

12. World Bank: Strategjia e Partneritetit te shtetit 2012-2015, Prishtine, fq.1-12

13. http://ec.europa.eu/enlargement/pdf/key_document/2012/package/ks_analitycal_2012_en.pdf

14. http://europa.eu/legislacion_summaries/

15. http://www.oecd.org/site/sigma/publicationsdocuments/48970710.pdf

16. $\underline{\text { http://www.mei-ks.net }}$ 